\title{
Tailoring communication in cancer genetic counseling through individual video-supported feedback: A controlled pretest-posttest design
}

\author{
Arwen H. Pieterse ${ }^{\mathrm{a}, *}$, Alexandra M. van Dulmen ${ }^{\mathrm{a}}$, Frits A. Beemer ${ }^{\mathrm{b}}$, \\ Margreet G.E.M. Ausems ${ }^{\mathrm{b}}$, Jozien M. Bensing ${ }^{\mathrm{a}, \mathrm{c}}$ \\ ${ }^{a}$ NIVEL (Netherlands Institute for Health Services Research), P.O. Box 1568, 3500 BN Utrecht, The Netherlands \\ ${ }^{\mathrm{b}}$ Department of Medical Genetics, University Medical Centre Utrecht, The Netherlands \\ ${ }^{\mathrm{c}}$ Department of Health Psychology, Utrecht University, The Netherlands
}

Received 16 March 2005; received in revised form 6 June 2005; accepted 8 June 2005

\begin{abstract}
Objectives: To assess the influence of a 1-day individual video-feedback training for cancer genetic counselors on the interaction during initial visits. Feedback was intended to help counselors make counselees' needs more explicit and increase counselors' sensitivity to these. Methods: In total 158 counselees, mainly referred for breast or colon cancer and visiting 1 of 10 counselors, received a pre- and post-visit questionnaire assessing needs (fulfillment). Visits were videotaped, counselor eye gaze was assessed, and verbal communication was analyzed by Roter Interaction Analysis System (RIAS) adapted to the genetic setting. Halfway the study, five counselors were trained.

Results: Trained counselors provided more psychosocial information, and with trained counselors emotional consequences of DNA-testing was more often discussed. Counselees seen by a trained counselor considered their need for explanations on (emotional) consequences of counseling as better fulfilled. Unexpectedly, counselees' contribution to the interaction was smaller with trained counselors.

Conclusion: Feedback appeared to result in greater emphasis on psychosocial issues, without lengthening the visit. However, counselors did not become more verbally supportive in other ways than by providing information.

Practice implications: A 1 day individual training appears effective to some extend; increased opportunities for watching and practicing behavioral alternatives and arranging consolidating sessions may improve training results.

(C) 2005 Elsevier Ireland Ltd. All rights reserved.

Keywords: Cancer genetic counseling; Communication; Feedback training; Needs
\end{abstract}

\section{Introduction}

Effective communication is a cancer genetic counselor's task par excellence. Ideally, counseling matches counselees' needs and preferences $[1,2]$ and the exchange of information should support individuals in coming to their own decisions, as put forward by the World Health Organization [3]. Authors have identified the provision of emotional support and reassurance as an important role for genetic counselors $[4,5]$. Earlier findings suggest that counselors do not adapt

\footnotetext{
* Corresponding author. Tel.: +31 302729 773; fax: +31 302729729 .

E-mail address: a.pieterse@nivel.nl (A.H. Pieterse).
}

their counseling to counselees' informational expectations [6,7] or current psychosocial state [7]. Counselors do appear to adapt their counseling to counselees' emotional needs by providing information, however not by exploring these needs more extensively nor by showing more empathy [6]. Additionally, a patient-centered approach as is advocated within counseling emphasizes the importance of clarifying counselees' needs, but genetic counselors appear to have difficulties understanding agenda's and needs of their clients [8]. Results suggest that patient-oriented agenda setting is a teachable and learnable skill [9]. More generally, training of physicians' communication skills can effectively alter their communication behaviors [10,11], especially where 
video-feedback of real doctor-patient encounters is provided [12], and can increase patients' participation during the visit [13]. These training interventions were performed in medical settings other than cancer genetic counseling. In the present study, counselors received a 1-day individual video-feedback training that was intended to help them make counselees' needs more explicit and to increase their sensitivity to these needs. We assessed the influence of the feedback training on the interaction during initial cancer genetic counseling visits. Counselor and counselee verbal communication was assessed, as well as counselors' eye gaze towards counselees, which appears a powerful instrument for detecting potential psychosocial problems $[12,14]$.

After training, psychosocial issues were likely to come more to the fore as it was expected that counselees' agenda would be more extensively discussed and counselors would spend more talk on clarifying counselees' needs. More specifically, counselors were expected to spend more time on discussing how aspects of counseling affect counselees (emotionally) and how to weight various types of information in deciding upon how to act on outcomes of counseling. Furthermore, trained counselors were expected to be less verbally dominating and to look relatively more at counselees compared to untrained counselors. Feedback was not expected to affect visit length, as previous studies revealed that the discussion of psychosocial issues does not automatically increase consultation time $[15,16]$. Feedback was further expected to affect counselor communication in accordance with counselees' particular pre-visit needs. Specifically, trained counselors were expected to pay more attention to counselees' informational and emotional needs by showing more empathy, by inquiring more about psychosocial issues, and by providing more information to counselees who had higher needs relating to these aspects in particular. In consequence, feedback was expected to increase the extent to which counselees felt their pre-visit needs were fulfilled during the visit. Finally, the training was not expected to affect the inclusion of core topics to be discussed during the visit, such as information on hereditary cancer and consequences of DNA-testing.

\section{Methods}

\subsection{Participating counselors}

All five clinical geneticists, four residents in clinical genetics (of whom two finished their training during the study period) and five genetic nurses (three finishing their training) providing cancer genetic counseling at the Department of Medical Genetics of the University Medical Centre Utrecht, The Netherlands, between March 2001 and August 2003, agreed to participate in the study. They will be referred to as 'counselor'. Of these, four counselors (one clinical geneticist, two residents and one genetic nurse) conducted only one consultation prior or following the intervention with a counselee participating in this study due to personal circumstances or switch of positions. These counselors were excluded from the analyses. The sample thus consisted of eight female and two male counselors, aged 30-46 years $(M=38.5 ; \quad$ S.D. $=5.7)$. Length of experience with cancer genetic counseling at the start of their participation in this study varied from less than 2 years $(N=5), 2-5$ years $(N=2)$ to more than 5 years $(N=3)$.

\subsection{Participating counselees}

All consecutive new referrals for cancer genetic counseling at the Department of Medical Genetics during the study period were approached. Inclusion criteria were aged 18 years or older and being the first in the family to seek genetic counseling. For 158 counselees, pre-visit questionnaire data and a videotape recording of the initial visit were available for analysis, and for 146/158 also post-visit questionnaire data were available (Fig. 1).

\subsection{Pretest-posttest control group design}

Halfway the study period, four female and one male counselor received feedback (Experimental condition), within a time period of 3 weeks. Trained counselors were expressly asked not to discuss the training with other counselors. Counselees were allocated to counselors as part of routine clinical practice. Selection for receiving feedback halfway was having conducted at least 10 visits with participating counselees. All counselors were eventually offered feedback, and the five counselors in the Control condition were trained after all initial visits were conducted.

\subsection{Feedback training}

A psychotherapist with expertise in the field of doctorpatient communication ran the meetings of the individual 1day $(8 \mathrm{~h})$ training. The training was aimed at identifying maladaptive communication skills (e.g., ignoring expressions of emotions), raising consciousness and understanding of the interaction process between counselor and counselee (e.g., structuring the interaction while leaving room for the other's own contribution), and encouraging alternative and more effective ways of communicating with counselees (e.g., inquiring about counselees' specific questions). In summary, the training combined:

1. Education on the significance of communicating affect (verbally and non-verbally), of addressing psychosocial issues, and of giving the counselee room to talk.

2. Discussion of videotapes of trainees' actual performance during encounters with counselees, in relation to counselees' data on importance attached to specific aspects of counseling prior to the visit, as measured in the pre-visit questionnaire. These discussions focused on 


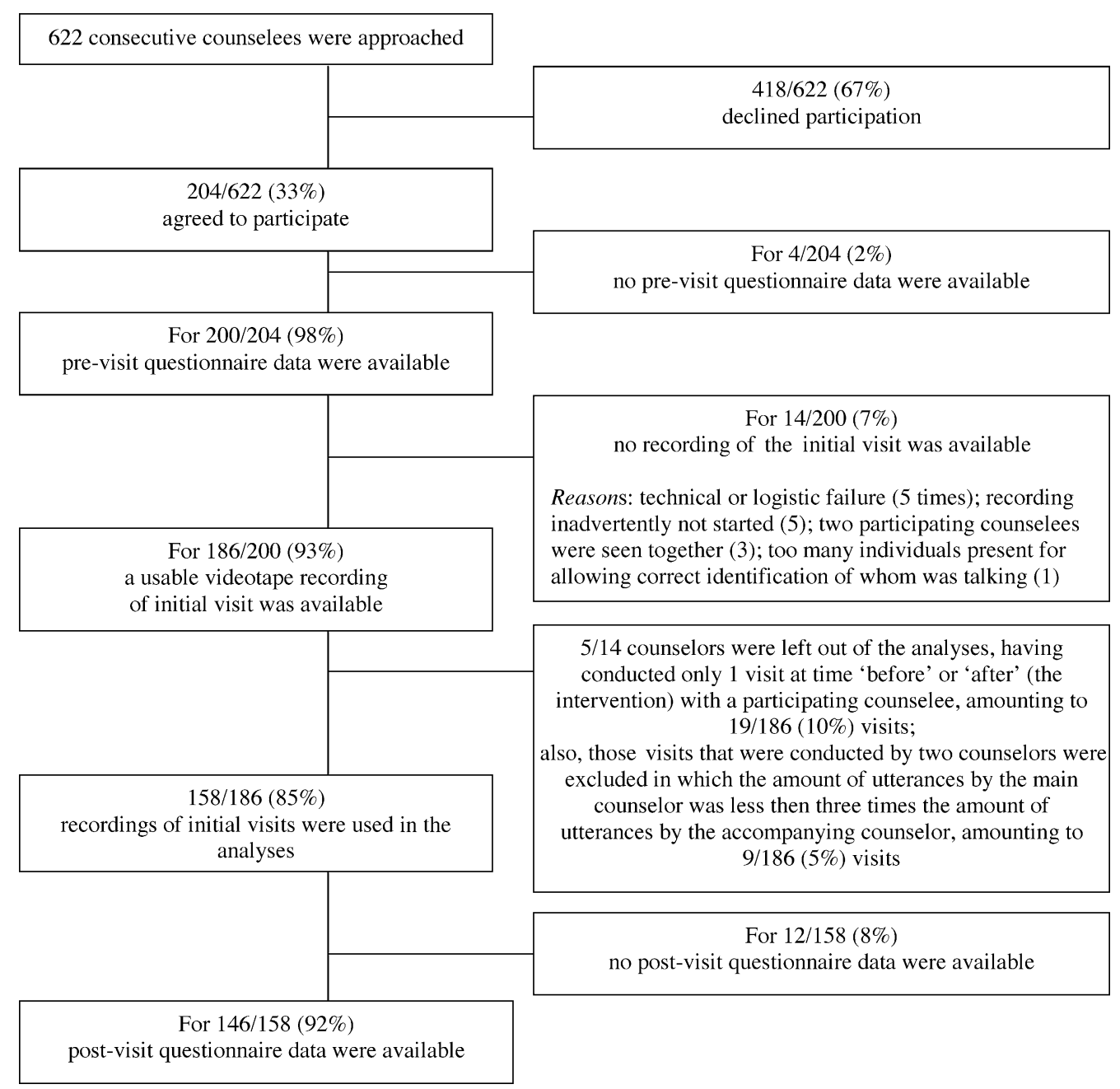

Fig. 1. Details of inclusion of counselees.

real-life examples of effective and less effective communication behaviors, giving insight into each counselor's characteristic way of communicating.

3. Discussion of the counselor's own experiences, in relation to personal learning objectives.

4. Role-play exercises, which provided the opportunity of becoming more comfortable with alternative communication skills.

These training techniques have been identified as educational methods of demonstrated effectiveness and feasibility $[13,17]$.

\subsection{Study procedure}

Approval of the Medical Ethical Committee of the university hospital was obtained to conduct the study, including the videotaping of consultations. The procedure of approaching eligible counselees is described elsewhere [18]. Participating counselees were asked to complete an informed consent form and a pre-visit questionnaire in the week before their first consultation. The consultation was videotaped. Recordings showed counselor's full face and counselees from behind or from the side. In 20 cases, a clinical geneticist accompanied a counselor still in training. These 20 visits were conducted before counselors had received feedback. At the end of the consultation, the counselor handed out the post-visit questionnaire and asked the counselee to complete it within a day.

\subsection{Coding of the videotapes}

Communication was coded through the use of the Observer computer system [19]. Four coders rated verbal communication using an adaptation of the Roter Interaction Analysis System (RIAS), a widely used observation system for coding physician-patient communication [20]. The adaptation is described elsewhere [6]. The system distinguishes socio-emotional and task-oriented communication. The coding system was adapted to code the exchange of pedigree data, medical information about relatives, communication within the family, and agenda. The main coder coded $54 \%$ of all consultations. The other coders independently coded a random $10 \%$ of the previous coded 
main coder's consultations. Reliability coefficients (Pearson's $r$ ) for categories with mean occurrence greater than $2 \%$ [21] proved to be adequate. The main coder recoded $10 \%$ of the consultations she previously had coded. Intra-coder reliability for counselor and counselee categories averaged 0.81 (range, 0.54-0.96) and 0.91 (range, 0.75-0.97), respectively. Inter-coder reliability for counselor and counselee categories averaged 0.78 (range, 0.54-0.98) and 0.83 (range, 0.59-0.97), respectively.

Additionally, the following four measures were assessed: counselor psychosocial focus, i.e., the ratio of psychosocial:biomedical questions and information, as a measure for counselee-centered communication; counselee's contribution to the encounter, i.e., the ratio of counselee's utterances: total count of utterances, as a measure of counselee's participation in the visit; counselee-directed gaze, as the time the counselor looked directly into the face of the counselee or his/her companion(s); and visit length.

Moreover, a checklist was designed to assess whether or not 11 specific topics were discussed during the visit. The choice of topics was informed by expert opinion and excluded pedigree and (family) history of cancer as these were considered as standard to counseling. Topics related to reasons for encounter (motive, referral, risk perceptions), predisposition to cancer (inheritance, prevalence of hereditary cancer, and medical consequences of carrying a cancer gene), and DNA-testing (possibilities, limitations, procedure, and medical and emotional consequences). Average inter-coder reliability over topics (Cohen's kappa) was 0.69.

\subsection{Questionnaire measures}

The counselee pre-visit questionnaire assessed gender, age, education, type of cancer for which counselees were seeking counseling, and number of affected first- and second-degree relatives. Information on counselee disease status was collected from their medical file.

The QUOTE-gene ${ }^{\text {ca }}[18]$, a counselee-centered instrument intended to measure importance attached to needs and preferences prior to cancer genetic counseling, was developed. Identical items were administered post-visit to measure need fulfillment. Respondents indicated pre-visit importance ('During counseling, the counselor should (explain) ...'; (1) 'not important', (2) 'fairly important', (3) 'important', and (4) 'extremely important') and postvisit performance ('During counseling, the counselor did (explain) ...'; (1) 'too little', (2) 'not really enough', (3) 'adequate', and (4) 'largely adequate'). Four generic needs were identified using Principal Component Analysis: (a) procedural aspects of counseling (eight items, Cronbach's $\left.\alpha_{\text {pre }}=0.86 ; \alpha_{\text {post }}=0.83\right)$, (b) counselor's sensitive communication (eight items, $\alpha_{\text {pre }}=0.82 ; \alpha_{\text {post }}=0.93$ ), (c) emotional support (five items, $\alpha_{\text {pre }}=0.77 ; \alpha_{\text {post }}=0.77$ ), and (d) assessment of susceptibility to the disease (three items, $\alpha_{\text {pre }}=0.65 ; \alpha_{\text {post }}=0.68$ ) (one item loaded equally on two dimensions). Similarly, four cancer-specific needs were identified on receiving explanations about: (a) determination and meaning of carrying a cancer gene (seven items, $\alpha_{\text {pre }}=0.83 ; \alpha_{\text {post }}=0.92$ ), (b) (emotional) aspects of counseling for counselee and family (five items, $\alpha_{\text {pre }}=0.71$; $\alpha_{\text {post }}=0.84$ ), (c) counselee's own risk of developing cancer (three items, $\alpha_{\text {pre }}=0.80 ; \alpha_{\text {post }}=0.83$ ), and (d) heredity of cancer in general (three items, $\alpha_{\text {pre }}=0.75 ; \alpha_{\text {post }}=0.70$ ) (one item loaded below 0.40 on any dimension). Importance and performance scores on each need were computed as the mean score on the relevant items (range scores 1-4).

\subsection{Statistical analyses}

Descriptive statistics were used to report counselor, counselee, and consultation characteristics. Where two participants were seen together by a counselor, counselee data were used for one (randomly selected) counselee only. If two counselors were present during the visit, characteristics of the counselor with the largest amount of utterances (the 'main' counselor) were retained. The similarity of distribution of counselee characteristics over visits in the Experimental versus Control conditions was tested using a $t$ test and $\chi^{2}$-tests. The similarity of distribution of counselor characteristics over the two conditions was not tested, due to the small number of counselors.

For analyzing the influence of feedback on communication, frequencies of counselor and counselee utterances were calculated. If two counselors were present, only those visits were retained for analysis in which the amount of utterances by the main counselor equaled at least three times the amount of utterances by the accompanying counselor. With regard to the remaining visits with two counselors, their utterances were added. Utterances of individuals accompanying counselees were not considered as the focus of this paper was on the counselees' needs. Verbal coding categories, where relevant, were combined on the basis of their content in line with the hypotheses (Appendix A). As several encounters per counselor were videotaped, to take account of the resemblance among encounters for one counselor, multilevel regression analysis was used.

Multilevel regression analyses were carried out in three steps. In step 1, background variables at the counselor level (gender, age, profession, years of experience), the counselee level (gender, age, education, personal and family history of cancer), and number of counselors present during the visit were included. The categories 'resident' and 'clinical geneticist' were aggregated into 'doctor' as opposed to 'genetic nurse'. Only significant correlates were retained.

In step 2, condition (Experimental versus Control), time (before versus after) and their interaction were included for assessing the overall influence of feedback. In the Experimental condition, visits conducted pre- versus post-feedback were coded as 'before' versus 'after'. In the Control condition, the first half of the consultations that each counselor conducted with a participant in the study was coded as 'before', and the second half as 'after'. For assessing the 
influence of feedback on counselor eye gaze relative to visit length, length of the visit was included in the model.

In step 3, where feedback was expected to affect communication in accordance with counselees' pre-visit needs, separate models were built for assessing the association between each need and communication behavior, including first- and second-order interactions between need, condition, and time. Needs were tested separately due to the large number of predictors in each model.

For assessing the overall influence of feedback on counselees' perceptions of need fulfillment, similar steps 1 and 2 were undertaken for each separate pre-visit need, with need fulfillment as outcome variable. For assessing the overall influence of feedback on the discussion (yes/no) of the various topics, multilevel logistic regression was conducted following the same two steps.

In all analyses, predictors at interval level measurement were recoded into standardized $z$-scores in order to afford a comparison of the relative contribution of these predictors, given the differing scales of measurement for needs and communication. In this manner, the regression parameter also corresponds to the correlation between the predictor and the outcome variable. Significance of the regression coefficients was tested using $\chi^{2}$-tests. Analyses were carried out using SPSS 11.5 and MLwiN 1.10. Significance testing was done at $\alpha=0.05$ level.

\section{Results}

\subsection{Participating counselors}

Counselor age, gender, profession, and years of experience with cancer genetic counseling in the Experimental $(N=5)$ versus Control $(N=5)$ conditions appeared very similar (Table 1$)$.

\subsection{Participating counselees}

Pre- and post-visit data and a videotape recording of the initial visit were available for analysis from 158 counselees (Fig. 1).
Counselee characteristics are summarized in Table 2. The counselees with a family history of cancer had $1-4(\mathrm{Md}=1)$ first-degree and 1-8 $(\mathrm{Md}=2)$ second-degree relatives diagnosed with cancer. Participants were, on average, 2.1 years older than decliners $(p=0.022)[18]$ however did not differ in gender, referral pathway, type of cancer, or (family) history of cancer. The counselees in the Experimental versus Control conditions, and those used in the analysis $(N=158)$ compared to those left out $(N=28)$, did not significantly differ in gender, age, educational level, or (family) history of cancer (data not shown).

\subsection{Consultations}

Visits lasted on average $43.9 \mathrm{~min}$ (S.D. $=14.3$ ). The counselors conducted 138/158 (87\%) visits alone. During the $20 / 158(13 \%)$ visits that were conducted by a clinical geneticist together with a genetic nurse, the main counselor averaged 519.8 statements $\quad($ S.D. $=145.1 ; \quad \min =284$, $\max =821$ ), compared to a mean of 66.0 utterances by the other counselor $($ S.D. $=54.4 ; \min =0, \max =169$ ). In $67 / 158(42.4 \%)$ visits, counselees had come alone. During all other visits, counselees were accompanied by one (51\%), or two or more (7\%) companions.

In the Experimental versus Control conditions, counselors conducted 105 (i.e., 50 pre- and 55 post-feedback) versus 53 visits (i.e., 25 at time 'before' and 28 at time 'after'), respectively.

\subsection{Influence of feedback on communication behavior}

Feedback significantly increased the counselors' psychosocial focus (Table 3). Contrary to expectation, counselees' relative contribution to the interaction was significantly smaller with trained compared to untrained counselors. As expected, feedback did not significantly alter mean length of the visit. With trained compared to untrained counselors, the discussion of counselees' agenda was not significantly different. Also, after feedback counselors did not look for longer towards counselees, neither in absolute terms (Table 3) nor relative to visit length (Beta $=0.24$, S.E. $=0.13, \mathrm{~ns})$.

Table 1

Counselor characteristics (frequencies) over Experimental vs. Control conditions $\left(N_{\mathrm{CR}}=10\right)$

\begin{tabular}{|c|c|c|c|}
\hline \multicolumn{2}{|l|}{ Counselor characteristics } & \multirow{2}{*}{$\begin{array}{l}\text { Experimental condition } \\
38.7(6.2)\end{array}$} & \multirow{2}{*}{$\frac{\text { Control condition }}{38.1(4.6)}$} \\
\hline Age (years) & Mean (S.D.) & & \\
\hline \multirow[t]{2}{*}{ Gender } & Female & 4 & 4 \\
\hline & Male & 1 & 1 \\
\hline \multirow[t]{2}{*}{ Profession } & Genetic nurse & 2 & 2 \\
\hline & Clinical geneticist or resident & 3 & 3 \\
\hline \multirow{3}{*}{$\begin{array}{l}\text { Length experience with cancer } \\
\text { genetic counseling (years) }\end{array}$} & $0-2$ & 3 & 2 \\
\hline & $2-5$ & 0 & 2 \\
\hline & $>5$ & 2 & 1 \\
\hline Total number of counselors & & 5 & 5 \\
\hline
\end{tabular}


Table 2

Counselee demographics, disease status and family history of cancer $(N=158)$

\begin{tabular}{|c|c|c|c|}
\hline & & $N$ & $\%$ \\
\hline \multirow[t]{2}{*}{ Age (years) } & Mean (S.D.) & $44.8(10.1)$ & \\
\hline & Range & $18-72$ & \\
\hline \multirow[t]{2}{*}{ Gender } & Female & 145 & 92 \\
\hline & Male & 13 & 8 \\
\hline \multirow[t]{2}{*}{ Education } & High school level & 90 & 57 \\
\hline & Secondary level & 67 & 43 \\
\hline \multirow[t]{5}{*}{ Type of cancer } & Breast cancer & 101 & 64 \\
\hline & Colon cancer & 29 & 18 \\
\hline & Breast and colon cancer & 10 & 6 \\
\hline & Ovarian cancer & 9 & 6 \\
\hline & Other cancers & 9 & 6 \\
\hline \multirow[t]{2}{*}{ Personal history of cancer } & Counselee affected with cancer & 67 & 42 \\
\hline & Counselee unaffected with cancer & 91 & 58 \\
\hline \multirow[t]{2}{*}{ Family history of cancer } & First- and/or second-degree relatives affected with cancer & 140 & 90 \\
\hline & No first- or second-degree relatives affected with cancer & 15 & 10 \\
\hline
\end{tabular}

Total numbers of cases do not add up to $N=158$ due to missing data.

Table 3

Results (Beta and standard error) on the overall influence of feedback ${ }^{\mathrm{a}}\left(N_{\mathrm{CR}}=10 ; N_{\mathrm{CE}}=158\right)$

\begin{tabular}{|c|c|c|c|c|c|c|c|c|c|c|}
\hline & \multicolumn{2}{|c|}{$\begin{array}{l}\text { Discuss CE } \\
\text { agenda }\end{array}$} & \multicolumn{2}{|c|}{$\begin{array}{l}\text { CR psychosocial } \\
\text { focus }\end{array}$} & \multicolumn{2}{|c|}{ CE contribution } & \multicolumn{2}{|c|}{ CR eye gaze } & \multicolumn{2}{|c|}{ Visit length } \\
\hline & Beta & S.E. & Beta & S.E. & Beta & S.E. & Beta & S.E. & Beta & S.E. \\
\hline \multicolumn{11}{|l|}{ Main effects } \\
\hline Condition & -0.11 & 0.33 & -0.04 & 0.24 & 0.21 & 0.24 & 0.05 & 0.32 & 0.06 & 0.33 \\
\hline Time & 0.26 & 0.23 & -0.07 & 0.25 & $0.67^{* * *}$ & 0.25 & 0.11 & 0.23 & 0.13 & 0.24 \\
\hline \multicolumn{11}{|l|}{ Interaction effect } \\
\hline Condition $\times$ time & -0.04 & 0.28 & $0.62^{*}$ & 0.32 & $-1.05^{* * * *}$ & 0.30 & 0.23 & 0.28 & -0.01 & 0.29 \\
\hline
\end{tabular}

CE: counselee; CR: counselor.

${ }^{a}$ Only significantly associated background variables were included in the final model.

${ }^{*} p<0.05$.

*** $p<0.01$.

**** $p<0.001$.

Table 4

Results (Beta and standard error) on the need-specific influence of feedback on various CR communication behaviors ${ }^{\mathrm{a}}\left(N_{\mathrm{CR}}=10 ; N_{\mathrm{CE}}=158\right)$

\begin{tabular}{|c|c|c|c|c|c|c|c|c|c|c|}
\hline & \multicolumn{2}{|c|}{$\begin{array}{l}\text { Discuss CE } \\
\text { agenda }^{\mathrm{b}}\end{array}$} & \multicolumn{2}{|c|}{ Empathy } & \multicolumn{2}{|c|}{$\begin{array}{l}\text { Psychosocial } \\
\text { questions }\end{array}$} & \multicolumn{2}{|c|}{$\begin{array}{l}\text { Psychosocial } \\
\text { information }^{c}\end{array}$} & \multicolumn{2}{|c|}{$\begin{array}{l}\text { Psychosocial } \\
\text { information }^{c}\end{array}$} \\
\hline & Beta & S.E. & Beta & S.E. & Beta & S.E. & Beta & S.E. & Beta & S.E. \\
\hline \multicolumn{11}{|l|}{ Main effects } \\
\hline Condition & -0.14 & 0.32 & $0.54^{*}$ & 0.22 & 0.30 & 0.23 & -0.09 & 0.23 & -0.11 & 0.23 \\
\hline Time & 0.28 & 0.23 & 0.30 & 0.24 & -0.09 & 0.26 & 0.08 & 0.26 & 0.07 & 0.26 \\
\hline \multicolumn{11}{|l|}{ Respective needs } \\
\hline CR sensitive communication & 0.02 & 0.17 & - & - & - & - & - & - & - & - \\
\hline Emotional support & - & - & -0.01 & 0.17 & 0.04 & 0.17 & -0.05 & 0.17 & - & - \\
\hline $\begin{array}{l}\text { (Emotional) aspects of counseling } \\
\text { for counselee/relatives }\end{array}$ & - & - & - & - & - & - & - & - & -0.07 & 0.17 \\
\hline \multicolumn{11}{|l|}{ Interaction effects ${ }^{\mathrm{d}}$} \\
\hline Condition $\times$ time & -0.03 & 0.28 & -0.06 & 0.30 & -0.09 & 0.32 & $0.64^{*}$ & 0.32 & $0.68^{*}$ & 0.32 \\
\hline Condition $\times$ time $\times$ need & -0.12 & 0.29 & -0.07 & 0.31 & 0.19 & 0.32 & -0.39 & 0.31 & 0.01 & 0.31 \\
\hline
\end{tabular}

CR: counselor; CE: counselee; -: association not hypothesized or not assessed within the model.

${ }^{\text {a }}$ Only significantly associated background variables were included in the final model.

b This communication variable includes CE information on agenda.

c Separate models were built to assess the association between each need and the communication behavior.

$\mathrm{d}$ The interaction parameters relating to condition $\times$ need and time $\times$ need are not shown.

* $p<0.05$. 
Table 5

Results (Beta and standard error) on the need-specific influence of feedback on CR medical information giving ${ }^{\mathrm{a}}\left(N_{\mathrm{CR}}=10 ; N_{\mathrm{CE}}=158\right)$

\begin{tabular}{|c|c|c|c|c|c|c|c|c|c|c|}
\hline & \multicolumn{2}{|c|}{$\begin{array}{l}\text { Medical } \\
\text { information }\end{array}$} & \multicolumn{2}{|c|}{$\begin{array}{l}\text { Medical } \\
\text { information }\end{array}$} & \multicolumn{2}{|c|}{$\begin{array}{l}\text { Medical } \\
\text { information }\end{array}$} & \multicolumn{2}{|c|}{$\begin{array}{l}\text { Medical } \\
\text { information }\end{array}$} & \multicolumn{2}{|c|}{$\begin{array}{l}\text { Medical } \\
\text { information }\end{array}$} \\
\hline & Beta & S.E. & Beta & S.E. & Beta & S.E. & Beta & S.E. & Beta & S.E. \\
\hline \multicolumn{11}{|l|}{ Main effects } \\
\hline Condition & 0.09 & 0.23 & -0.28 & 0.22 & 0.03 & 0.23 & -0.21 & 0.23 & 0.00 & 0.24 \\
\hline Time & 0.45 & 0.23 & 0.34 & 0.24 & 0.40 & 0.23 & 0.37 & 0.23 & 0.40 & 0.24 \\
\hline \multicolumn{11}{|l|}{ Respective needs } \\
\hline $\begin{array}{l}\text { Explanations on procedural } \\
\text { aspects of counseling }\end{array}$ & 0.11 & 0.17 & - & - & - & - & - & - & - & - \\
\hline $\begin{array}{l}\text { Assessment of cancer } \\
\text { susceptibility }\end{array}$ & - & - & -0.35 & 0.21 & - & - & - & - & - & - \\
\hline $\begin{array}{l}\text { Determination/meaning of } \\
\text { carrying a cancer gene }\end{array}$ & - & - & - & - & -0.15 & 0.17 & - & - & - & - \\
\hline $\mathrm{CE}$ own risk of cancer & - & - & - & - & - & - & -0.08 & 0.17 & - & - \\
\hline Heredity of cancer & - & - & - & - & - & - & - & - & 0.05 & 0.16 \\
\hline \multicolumn{11}{|l|}{ Interaction effects $^{\mathrm{b}}$} \\
\hline Condition $\times$ time & -0.05 & 0.28 & 0.07 & 0.29 & 0.03 & 0.29 & 0.10 & 0.29 & 0.00 & 0.29 \\
\hline Condition $\times$ time $\times$ need & -0.16 & 0.29 & -0.04 & 0.32 & 0.14 & 0.28 & 0.36 & 0.30 & 0.08 & 0.31 \\
\hline
\end{tabular}

CR: counselor; CE: counselee; -: association not assessed within the model.

${ }^{a}$ Only significantly associated background variables were included in the final model. Separate models were built to assess the association between each need and CR medical information giving.

b The interaction parameters relating to condition $\times$ need and time $\times$ need are not shown.

Trained counselors provided overall significantly more psychosocial information (Table 4) compared to untrained counselors. Feedback did not significantly affect other counselor utterances, neither overall, nor in interaction with counselees' pre-visit needs (Tables 4 and 5).

\subsection{Discussion of topics during the visit}

The topics assessed were similarly discussed prior and after feedback, with the exception of emotional consequences of DNA-testing, a subject talked about more often in visits with trained compared to untrained counselors $(B=2.37$, S.E. $=0.75, p=0.002)$.

\subsection{Fulfilling counselees' pre-visit needs}

Counselees who were seen by a trained compared to an untrained counselor considered their pre-visit need for explanations on (emotional) aspects of counseling as better fulfilled (Beta $=0.91$, S.E. $=0.28, p=0.011)$. Counselees' perceptions of the fulfillment of other needs did not significantly differ between those seen by a trained compared to an untrained counselor.

\section{Discussion and conclusion}

Overall, this study showed moderate support for the assertion that genetic counselors can be taught to provide more room for psychosocial issues during initial cancer genetic counseling visits by facing them with their own communication behavior.

\subsection{Specific communication behaviors}

The training was specially designed to help counselors to clarify and be more attentive to counselees' needs, and to help them become less verbally dominating. Trained counselors' focus during the visit was significantly more psychosocial compared to untrained counselors, which is regarded as important in medical practice [5,13]. Trained counselors did not look longer towards counselees, suggesting that training did not result in intensified nonverbal attention during visits. Contrary to expectation, trained counselors' verbal dominance was not smaller. Counselees' relative contribution to the interaction was even smaller with trained compared to untrained counselors. Mean length of the visits was not different with trained and untrained counselors and while trained counselors offered more psychosocial information, they did not provide less of other types of information. The training did not alter the amount of medical information they gave, thus preserving attention for the main goal of educating individuals about cancer risk and risk management. This is illustrated by the invariance in covering medical topics, with and without training. With trained counselors emotional consequences of DNA-testing were discussed more often, a finding reflecting counselors' increased psychosocial focus. Yet, training did not help counselors in giving counselees more room in the interaction, in terms of quantity of speech. Nevertheless, counselees' contribution may have been qualitatively more effective. That is, with trained counselors counselees may have been better enabled to formulate succinctly what they meant to ask or tell, through a stronger attention for nonmedical issues and/or more non-verbal attention. A content 
analysis of the interaction would be necessary in order to assess the validity of this proposition. Still, and contrary to other interventions [13], the training was individual and limited in time. It may therefore have presented less opportunities for watching and practicing behavioral alternatives.

With trained counselors, the influence of counselee previsit needs on counselor behavior was not greater than with untrained counselors. Trained counselors did not show more empathy verbally, nor did they ask more psychosocial questions. These results suggest that the training did not succeed in helping counselors become more verbally supportive in other ways than by providing information. Doctors consider it difficult to enquire actively about cancer patients' concerns and feelings $[11,22]$. However, authors have suggested that task-related communication such as the exchange of information, may be more effective in conveying a consistent message of interest and concern than socio-emotional communication [23]. At the same time, a parallel intervention targeted at counselees and aimed at facilitating their involvement during the visit may be helpful in increasing counselee expression. This has been done with cancer patients by sending them a comprehensive and easy to understand booklet in advance of their visit [24].

\subsection{Limitations}

The number of participating counselors was small, and they were appointed at the same genetic clinic, diminishing the power and generalizability of the findings. Training effects between males and females, counselors with differing professions, or counselors with differing length of experience could not be assessed. In addition, least experienced counselors (i.e., those in training) were accompanied by an experienced counselor (i.e., clinical geneticist) during visits. So the influence of training on the least experienced counselors could not be determined. Moreover, learning effect from conducting visits with counselees that did not participate in our study could not be accounted for.

During the study period, a number of residents and genetic nurses switched of subject area and spent only part of their time doing cancer genetic counseling. Therefore, they conducted less visits than was originally planned. In addition, participation rate of counselees in the study was low. Refusal rate is discussed elsewhere [18]; it may have been due to procedural requirements for indicating interest in participation or to videotaping. It is unknown whether participants and decliners differed on other aspects than socio-demographics, including their needs, and thus how representative our sample is for the larger population that attends family cancer clinics.

Moreover, the training was short, lasting only 1 day. It was intensive though, in that it was given one-to-one and made use of an extensive training method, including individualized video-supported feedback. Nevertheless, more effects may be detected with a longer term training [25]. Training usually first changes trainees' attitude and enough time is necessary to translate intention to performance, or more specifically, to acquire new skills that may be used in daily practice [10]. Moreover, we did not assess longer term effects of training. Research suggests that with time, newly acquired skills may increasingly be used in practice [11,26], especially after following consolidating sessions [26].

\subsection{Conclusion}

This study showed that an individual 1-day feedback training for counselors may positively affect the interaction during initial cancer genetic counseling visits, without lengthening it. With trained counselors, there appeared to be a greater emphasis on psychosocial issues in general and in talking about emotional consequences of DNA-testing specifically, during the visit. Also, counselees seen by a trained counselor perceived their need for explanations on (emotional) consequences of counseling for them or their relatives to be better fulfilled, compared to those seen by an untrained counselor. These results further appear to support findings that providers can acquire new communication skills and translate them into practice [10], as well as the effectiveness of a training comprising feedback about real encounters [12]. Trained counselors did not appear to ask more psychosocial questions than untrained counselors. Further research is needed with a longer follow-up period and a larger sample of counselors, to assess lasting and differential training effects in counselors.

\subsection{Practice implications}

The findings within this study suggest that reviewing and discussing actual performance with practicing cancer genetic counselors in light of the importance of addressing psychosocial issues, communicating affect and giving the counselee room to talk, may be helpful in increasing attention to psychosocial issues and better addressing counselees' pre-visit needs during real encounters. Increased opportunities for watching and practicing behavioral alternatives and arranging consolidating sessions may improve training results.

\section{Acknowledgements}

We are thankful to the clinical geneticists, residents in clinical genetics and genetic nurses of the Department of Medical Genetics at the University Medical Centre Utrecht, The Netherlands, who participated in this study. The study was supported by a grant from the Dutch Cancer Society. 


\section{Appendix A}

Counselor (CR) and counselee (CE) communication categories used in the analyses

\begin{tabular}{|c|c|c|}
\hline Categories used in analyses & Component categories (if applicable) & Explanation of category \\
\hline \multicolumn{3}{|l|}{ Socio-emotional communication } \\
\hline \multirow[t]{3}{*}{ CR empathy } & Concern & Immediate emotional or psychosocial worries \\
\hline & Verbal attention & Legitimize, empathy, partnership, support \\
\hline & Reassurance & Give reassurance \\
\hline \multicolumn{3}{|l|}{ Task-related communication } \\
\hline CR medical information & - & $\begin{array}{l}\text { Statements or facts relating to medical condition or screening } \\
\text { or prophylactic surgery }\end{array}$ \\
\hline CR psychosocial questions & - & $\begin{array}{l}\text { Questions that ask for information on psychosocial } \\
\text { issues }^{\mathrm{a}} \text { or current feelings }\end{array}$ \\
\hline \multirow[t]{2}{*}{ CR psychosocial information } & CR psychosocial information & Statements or facts relating to psychosocial issues ${ }^{\mathrm{a}}$ or current feelings \\
\hline & CR psychosocial education & $\begin{array}{l}\text { Statements which suggest resolution or action to be taken by the } \\
\text { other relating to psychosocial issues }{ }^{\mathrm{a}} \text { or statements aimed } \\
\text { at education about psychosocial issues }\end{array}$ \\
\hline \multirow[t]{4}{*}{ CR psychosocial focus } & CR psychosocial questions & $\begin{array}{l}\text { Computed as the ratio of psychosocial to medical } \\
\text { questions and information }\end{array}$ \\
\hline & CR psychosocial information/education & \\
\hline & $\mathrm{CR}$ medical questions & \\
\hline & CR medical information & \\
\hline \multirow[t]{2}{*}{ Discuss CE agenda } & CR question agenda & Questions that ask for information on CE's agenda \\
\hline & CE information agenda & Statements or facts relating to CE's agenda \\
\hline \multicolumn{3}{|c|}{ Overall communication measures } \\
\hline CE contribution & - & $\begin{array}{l}\text { Computed as the ratio of all CE utterances to the total count of } \\
\text { utterances of all individuals present during the visit }\end{array}$ \\
\hline CR eye gaze & - & $\begin{array}{l}\text { Length in minutes of time that the CR looks directly into the face of } \\
\text { the CE or his/her companion(s) }\end{array}$ \\
\hline
\end{tabular}

\footnotetext{
${ }^{a}$ Psychosocial issues encompass the discussion of feelings and emotions that are not active at the moment, as well as discussion about ways in which
} counselees (or relatives) make decisions related to the problem for which they sought counseling.

\section{References}

[1] Bernhardt BA, Biesecker BB, Mastromarino CL. Goals, benefits, and outcomes of genetic counseling: client and genetic counselor assessment. Am J Hum Genet 2000;94:189-97.

[2] Lobb EA, Butow P, Meiser B, Tucker K, Barratt A. How do geneticists and genetic counselors counsel women from high-risk breast cancer families? J Genet Couns 2001;10:185-99.

[3] Proposed international guidelines on ethical issues in medical genetics and genetic services (Part II). World Health Organization, Human Genetics Programme. Law Hum Genome Rev 1998; 239-51.

[4] Kelly PT. Will cancer risk assessment and counseling services survive genetic testing? Acta Oncol 1999;38:743-6.

[5] Stopfer JE. Genetic counseling and clinical cancer genetics services. Semin Surg Oncol 2000;18:347-57.

[6] Pieterse AH, Van Dulmen AM, Ausems MGEM, Beemer FA, Bensing JM. Communication in cancer genetic counselling: Does it reflect counselees' pre-visit needs and preferences? Br J Cancer 2005; 92:1671-8.

[7] Lobb EA, Butow PN, Meiser B, Barratt A, Gaff C, Young MA, Kirk J, Suthers GK, Tucker K. Tailoring communication in consultations with women from high risk breast cancer families. $\mathrm{Br} \mathrm{J}$ Cancer 2002;87:502-8.

[8] Michie S, Bron F, Bobrow M, Marteau TM. Nondirectiveness in genetic counselling: an empirical study. Am J Hum Genet 1997; 60:40-7.

[9] Smith RC, Lyles JS, Mettler J, Stoffelmayr BE, Van Egeren LF, Marshall AA, Gardiner JC, Maduschke KM, Stanley JM, Osborn GG, Shebroe V, Greenbaum RB. The effectiveness of intensive training for residents in interviewing. A randomized, controlled study. Ann Intern Med 1998;128:118-26.
[10] Hulsman RL, Ros WJG, Winnubst JAM, Bensing JM. Teaching clinically experienced physicians communication skills. A review of evaluation studies. Med Educ 1999;33:655-68.

[11] Fallowfield L, Jenkins V, Farewell V, Saul J, Duffy A, Eves R. Efficacy of a cancer research UK communication skills training model for oncologists: a randomised controlled trial. Lancet 2002;359:650-6.

[12] Davenport S, Goldberg D, Millar T. How psychiatric disorders are missed during medical consultations. Lancet 1987;2:439-41.

[13] Van Dulmen AM, Van Weert JCM. Effects of gynaecological education on interpersonal communication skills. Br J Obstet Gynaecol 2001;108:485-91.

[14] Bensing JM, Kerssens JJ, Van der Pasch M. Patient-directed gaze as a tool for discovering and handling psychosocial problems in general practice. J Nonverbal Behav 1995;19:223-42.

[15] Dugdale DC, Epstein R, Pantilat SZ. Time and the patient-physician relationship. J Gen Intern Med 1999;14(Suppl. 1):S34-40.

[16] Van Dulmen AM, Holl RA. Effects of continuing paediatric education in interpersonal communication skills. Eur J Pediatr 2000;159:489_ 95.

[17] Roter D, Hall J, Kern D, Barker L, Cole K, Roca R. Improving physicians' interviewing skills and reducing patients' emotional distress. A randomized clinical trial. Arch Intern Med 1995; 155:1877-84.

[18] Pieterse A, Van Dulmen S, Ausems M, Schoemaker A, Beemer F, Bensing J. QUOTE-gene ${ }^{\text {ca }}$ : development of a counselee-centered instrument to measure needs and preferences in genetic counseling for hereditary cancer. Psychooncology 2005;14:361-75.

[19] Noldus L, Trienes R, Hendriksen A, Jansen H, Jansen R. The Observer Video-Pro: new software for the collection, management, and presentation of time-structured data from videotapes and digital media files. Behav Res Meth Instrum Comput 2000;32:197-206. 
[20] Roter D, Larson S. The Roter interaction analysis system (RIAS): utility and flexibility for analysis of medical interactions. Patient Educ Couns 2002;46:243-51.

[21] Roter D, Lipkin Jr M, Korsgaard A. Sex differences in patients' and physicians' communication during primary care medical visits. Med Care 1991;29:1083-93.

[22] Maguire P, Faulkner A. Improve the counselling skills of doctors and nurses in cancer care. Br Med J 1988;297:847-9.

[23] Roter DL, Hall JA, Katz NR. Relations between physicians' behaviors and analogue patients' satisfaction, recall, and impressions. Med Care 1987;25:437-51.

[24] Butow P, Devine R, Boyer M, Pendlebury S, Jackson M, Tattersall MH. Cancer consultation preparation package: changing patients but not physicians is not enough. J Clin Oncol 2004;22: 4401-9.

[25] Fallowfield L, Lipkin M, Hall A. Teaching senior oncologists communication skills: results from phase I of a comprehensive longitudinal program in the United Kingdom. J Clin Oncol 1998; 16:1961-8.

[26] Razavi D, Merckaert I, Marchal S, Libert Y, Conradt S, Boniver J, Etienne AM, Fontaine O, Janne P, Klastersky J, Reynaert C, Scalliet P, Slachmuylder JL, Delvaux N. How to optimize physicians' communication skills in cancer care: results of a randomized study assessing the usefulness of posttraining consolidation workshops. J Clin Oncol $2003 ; 21: 3141-9$. 